\title{
The validity and reliability study for evaluation of factors affecting workplace satisfaction of academic staff: faculty of veterinary medicine
}

\author{
Mustafa Agah TEKINDAL 1, a*, Mehmet Emin TEKIN 1, b, Mustafa Bahadır ÇEVRIMLI 2, $c$, \\ Gökhan ASLIM ${ }^{3, d}$, Burak MAT ${ }^{2, e}$, Aytekin GÜNL $\ddot{U}^{2, f}$, Aşkın YAŞAR ${ }^{3, g}$ \\ ${ }^{1}$ Selcuk University, Faculty of Veterinary Medicine, Department of Biostatictics Konya, Turkey \\ ${ }^{2}$ Selcuk University, Faculty of Veterinary Medicine, Department of Livestock Economics and Management Konya, Turkey \\ ${ }^{3}$ Selcuk University, Faculty of Veterinary Medicine, Department of History of Veterinary Medicine and Deontology Konya, Turkey \\ ORCID: 0000-0002-4060-7048 ${ }^{a}$; 0000-0002-3449-9984 ${ }^{b}$; 0000-0001-5888-242X ${ }^{c}$; 0000-0001-5976-8186 ${ }^{d}$; 0000-0002-0455-8736 ${ }^{e}$; 0000-0002-1989- \\ $8119^{f} ; 0000-0001-8641-6207^{g}$
}

\section{MAKALE BILGisi: \\ ARTICLE \\ INFORMATION: \\ Geliş / Received: \\ 15 Nisan 2019 \\ 15 April 2019}

Kabul / Accepted:

08 Ekim 2019

08 October 2019

Anahtar Sözcükler:

Akademisyen

Geçerlilik

Güvenirlik

Mcdonals $\omega$

memnuniyet ölçeği

Keywords:

Mcdonals $\omega$

Reliability

satisfaction

Scale for academic

Valitidy
ABSTRACT:

The present study is intended to identify the factors affecting the workplace satisfaction of the academic staff at a faculty of veterinary medicine. Additionally, it aims to develop a scale for evaluating the workplace satisfaction of the faculty members at the veterinary faculty (Job Satisfaction Evaluation Scale for Academic Staff). Eighty-eight members of the academic staff serving at Selçuk University Faculty of veterinary medicine participated in the study. For construct validity, Cronbach's alpha $(\alpha)$ and McDonald's omega $(\omega)$ tests were conducted in the reliability analyses. Factor analysis was conducted for analysis of validity. A scale was developed, consisting of 4 factors and 26 items in total. The sociodemographic variables affecting the factors and the total scores that can be obtained from a form for which a reliability and validity study has been conducted may vary even among the departments/faculties in the same university. As a recommendation, similar studies can be conducted annually in several universities across the country using scales whose validity and reliability have been confirmed, as a result of which the universities can identify their strengths and weaknesses according to some factors, and administrators of the universities can consider such results when making decisions for improvement and development of the universities. Implementation of improvement measures will directly or indirectly contribute to the development of countries and the welfare of society.

\section{Akademik personelin işyerinde memnuniyetini etkileyen faktörleri ölçeği geçerlik ve güvenirlik çalışması: veteriner fakültesi örneği}

ÖZET:

$\mathrm{Bu}$ çalışma ile veteriner fakültesinde görev yapan akademik personelin iş ortamında memnuniyetine etkili faktörlerin belirlenmesi amaçlanmıştır. Buna ilaveten veteriner fakültesi öğretim elemanlarının iş ortamından memnuniyetini değerlendirmesini mümkün kılan bir ölçeğin (Akademik Personel İş Memnuniyeti Değerlendirme Ölçeği) geliştirilmesi hedeflenmiştir. Çalışmaya Selçuk Üniversitesi Veteriner Fakültesi bünyesinde görev yapan 88 akademik personel katılmıştır. Yapı geçerliliği için; güvenirlik analizlerinde Cronbach alfa $(\alpha)$ ve McDonald's $\omega$ katsayısı kullanılmıştır. Geçerlik analizi için faktör analizi uygulanmıștır. Calıșmadan faktör analizi sonucunda 26 maddeden oluşan 4 alt faktörlü bir ölçek geliştirilmiştir. Güvenirlik ve geçerlik çalışması yapılmış bir formdan elde edilecek toplam puanlamalar ve alt faktörleri etkileyen sosyo-demografik değișkenler aynı üniversite bünyesinde bile birimler itibariyle farklılık gösterebilmektedir. Öneri olarak geçerlik ve güvenirliği sağlanmış fakülte özelinden geliştirilmiş ölçeklerle ülke çapında üniversiteler bünyesinde yıllık benzer çalıșmalar yaptırılması neticesinde üniversiteler kendi içinde bir takım alt faktörler itibariyle güçlü ve zayıf yönlerini tespit edebilecek, elde edilecek sonuçlar üniversitelerde bir takım iyileşme ve gelişme yönünde alınacak kararlarda yöneticilere fikir verici nitelikte olabilecektir. İyileștirici tedbirlerin hayata geçirilmesi dolaylı veya direk olarak ülkelerin gelişmesine ve toplumun refahının iyileşmesine de katkı sağlayacağı düşünülmektedir. 


\section{Introduction}

Employee satisfaction should be addressed as a crucial issue that affects employees and employers in both the public and the private sectors (21). Additionally, if employees are satisfied with their job at an expected level, their quality of life is improved, which contributes to the enhancement of their organisation's performance $(21,24)$. There is abundant research on the factors affecting job satisfaction. While such studies have some common factors affecting job satisfaction, there is no standardised factor classification. Factors affecting job satisfaction that are addressed in various studies include wage, promotion status, benefit from the job, workplace conditions, relationships with colleagues, management's attitude, mode of supervision, rewarding, and development opportunities (13, 19, 22, 24, 25).

Specifically for academic staff, the factors that may affect workplace satisfaction differ from those in other workplaces. The differences include an academic incentive, cooperation/solidarity between employees, job satisfaction, satisfaction from administrative activities, positive attitude and behaviour of the management, and communication with other units (2).

As employees' workplace environment and the quality and quantity of the tasks carried out by them differ from each other, the conducting of such type of studies at the level of workplace environment of relevant organisations will allow study results to be more reliable and valid. Similar measurements carried out on different samples may give different results. Considering the abovementioned reasons, the present study was conducted on academic staff, with a focus on evaluating/identifying the factors affecting their level of workplace satisfaction.

\section{Material and Methods}

Delphi method was employed during the development of the data collection form. Delphi Technique: It is the process of obtaining the common opinions of a selected expert group on a subject with a rational approach. The evaluation forms that had been regularly distributed to academic staff every year were compiled, and a 52-question form was developed for evaluation of academic staff's workplace satisfaction in collaboration with the academic staff serving in such evaluation commissions in Selçuk University Faculty of veterinary medicine.

Eighty-eight members serving in the veterinary faculty in the academic year 2017-2018 participated in the study.

Internal consistency method was used for reliability and criterion validity methods were used for validity.

For construct validity, Cronbach's alpha $(\alpha)$ and McDonald's omega $(\omega)$ tests were conducted in the reliability analyses. Factor analysis was conducted for analysis of validity. Fitness for factor analysis was checked by Bartlett's sphericity test and adequacy of the sample size by Kaiser-Meyer-Olkin test. The scale items were determined in a construct composed of four factors by Quartimax rotation method. Quartimax rotation is an orthogonal alternative that minimizes the number of factors needed to explain each variable. Such rotation is often a general factor in which most of the variables are loaded high or medium. The additivity of the scales was checked by Tukey's test of additivity. The data were evaluated via SPPS 25 (IBM Corp. Released 2017. IBM SPSS Statistics for Windows, Version 25.0. Armonk, NY: IBM Corp.). $\mathrm{p}<0.05$ and $\mathrm{p}<0.01$ were taken as significance levels.

\section{Results}

Validity and reliability are indicators of usability of the measurement tool. Validity is the degree to which the measurement tool accurately measures what it is intended to measure and serves the purpose for which it was developed. The validity of scales is usually composed of two types of validity evidence: construct validity and content validity (9). For the content validity of the Turkish version of the scale, the opinions of experts specialised in this field need to be considered as well as reviewing the statement of the items, content details and fitness of the scale for the area of research. Upon such reviews, the content validity of the scale should be high enough to represent all facets of the construct. In order to measure content validity, the scale is submitted to experts specialised in the relevant field for evaluation and, as appropriate, revised according to the results of the evaluation (20). The agreement of the experts in relation to the applicability and intelligibility of the items is a criterion for the content validity of the scale (15). 
Tablo 1. Faktör Yüklerinin Kareler Toplamı

Table 1. Sum of Squared Factor Loadings

\begin{tabular}{cccc}
\hline Factor & Total & $\begin{array}{c}\text { Rotation Sums of Squared Loadings } \\
\text { \% of Variance }\end{array}$ & Cumulative \% \\
\hline 1 & 4.73 & 18.21 & 18.21 \\
2 & 3.54 & 13.61 & 31.82 \\
3 & 3.15 & 12.11 & 43.93 \\
4 & 2.55 & 9.79 & 53.73 \\
\hline
\end{tabular}

Kaiser-Meyer-Olkin Sample Adequacy $=0.774$

Bartlett's sphericity test chi-square statistic $=1012.414$

Degree of freedom $325 p=0.0001$

Considering the total explained variance in Table 1, there are four factors for 26 out of 52 items that have an item-total correlation below 0.20 , and $53.73 \%$ of what is measured by this 4 -factor measurement tool is measured. The construct validity measured by the factor analysis method is defined as the degree of accuracy of the evidence for the theoretical construct that is intended to be measured $(3,11)$. Before the factor analysis, a KMO value below indicates the sample size is not adequate, while a KMO value between 0.60 and 0.69 indicates the sample size is fine. Additionally, the result of Bartlett's sphericity test should be statistically significant to check for the adequacy of the sample size $(16,17)$. In the present study, the KMO value was found to be 0.70 and Bartlett's test sphericity chi-square statistic was found to be $\chi^{2}=1012.414$. This result was found to be statistically significant $(\mathrm{p}<0.01)$. Therefore, it can be said that these data are suitable for factor analysis $(\mathrm{p}<0.05)$. Overall, the measurement tool has construct validity according to the results of the factor analysis. The values obtained in the study indicate that the sample is adequate for factor analysis. In order to measure the validity of the scale, factor analysis was conducted on the data collected by the items in the questionnaire using the Quartimax method, the results of which are given in Tables 2 and 3.

Tablo 2: Tukey Toplanabilirlik Testi

Table 2: Tukey's Test of Additivity

\begin{tabular}{|c|c|c|c|c|c|c|c|}
\hline & & & $\begin{array}{c}\text { Sum of } \\
\text { Squares }\end{array}$ & df & $\begin{array}{c}\text { Mean } \\
\text { Square }\end{array}$ & $\mathbf{F}$ & Sig \\
\hline \multicolumn{3}{|l|}{ Between People } & 264.831 & 85 & 3.116 & & \\
\hline \multirow[t]{5}{*}{ Within People } & \multicolumn{2}{|c|}{ Between Items } & 244.240 & 51 & 4.789 & 11.540 & .001 \\
\hline & Residual & Nonadditivity & 6.176 & 1 & 6.176 & 14.931 & .001 \\
\hline & & Balance & 1792.795 & 4334 & .414 & & \\
\hline & & Total & 1798.971 & 4335 & .415 & & \\
\hline & \multicolumn{2}{|l|}{ Total } & 2043.212 & 4386 & .466 & & \\
\hline \multicolumn{3}{|l|}{ Total } & 2308.043 & 4471 & .516 & & \\
\hline
\end{tabular}

Tukey's test of additivity was conducted to obtain a total score for the scale by adding the scores for the items, as shown in Table 2. The results of the test of additivity indicate that the scale is suitable for obtaining a total score by adding the scores for the items, as the level of significance is $\mathrm{p}<0.05$. 
Tablo 3: Faktörlere göre belirlenmiş faktör yükleri

Table 3: Factor loadings

\begin{tabular}{|c|c|c|c|c|c|}
\hline $\begin{array}{l}\text { Item } \\
\text { No. }\end{array}$ & $\begin{array}{l}\text { Job Satisfaction Evaluation Scale } \\
\text { for Academic Staff }\end{array}$ & $\begin{array}{c}\text { Adequacy of } \\
\text { School } \\
\text { Infrastructure } \\
\end{array}$ & Management & $\begin{array}{c}\text { Social } \\
\text { Opportunities }\end{array}$ & Courses/Education \\
\hline 1 & $\begin{array}{l}\text { The number of courses in our school is adequate for } \\
\text { veterinary education. }\end{array}$ & 0.515 & & & \\
\hline 2 & $\begin{array}{l}\text { The laboratories in our school are adequate for } \\
\text { veterinary education. }\end{array}$ & 0.510 & & & \\
\hline 3 & $\begin{array}{l}\text { The classrooms at our school are adequate for } \\
\text { veterinary education. }\end{array}$ & 0.484 & & & \\
\hline 4 & $\begin{array}{l}\text { The internship programme for our students is } \\
\text { satisfactory. }\end{array}$ & 0.557 & & & \\
\hline 7 & Senior students in our school are sufficiently qualified. & 0.598 & & & \\
\hline 10 & $\begin{array}{l}\text { The number of academic staff in your department is } \\
\text { adequate. }\end{array}$ & 0.732 & & & \\
\hline 11 & The infrastructure of your department is satisfactory. & 0.707 & & & \\
\hline 12 & $\begin{array}{l}\text { The number of publications at the national level in } \\
\text { your department is sufficient. }\end{array}$ & 0.588 & & & \\
\hline 13 & $\begin{array}{l}\text { The number of publications at international level in } \\
\text { your department is sufficient. }\end{array}$ & 0.693 & & & \\
\hline 14 & $\begin{array}{l}\text { The communication between the members of the } \\
\text { academic staff in your department is satisfactory. }\end{array}$ & 0.636 & & & \\
\hline 15 & $\begin{array}{l}\text { The cooperation between your department and other } \\
\text { units is satisfactory. }\end{array}$ & 0.703 & & & \\
\hline 23 & $\begin{array}{l}\text { The level of communication between the school and } \\
\text { the local community (residents of Konya) is } \\
\text { satisfactory. }\end{array}$ & & & 0.690 & \\
\hline 24 & $\begin{array}{l}\text { The communication between the school and } \\
\text { professional bodies (chambers, associations, societies, } \\
\text { foundations) is satisfactory. }\end{array}$ & & & 0.580 & \\
\hline 26 & The social activities carried out are satisfactory. & & & 0.518 & \\
\hline 28 & $\begin{array}{l}\text { Green and landscaped spaces and parks are } \\
\text { satisfactory. }\end{array}$ & & & 0.722 & \\
\hline 29 & The school's car parks are satisfactory. & & & 0.784 & \\
\hline 32 & The webpage of our school is satisfactory. & & & 0.586 & \\
\hline 37 & The curriculum of our school is intensive. & & & & 0.572 \\
\hline 38 & $\begin{array}{l}\text { The number of elective courses in our school should be } \\
\text { increased. }\end{array}$ & & & & 0.794 \\
\hline 39 & $\begin{array}{l}\text { It is appropriate if the students evaluate the academic } \\
\text { staff and the courses. }\end{array}$ & & & & 0.510 \\
\hline 41 & $\begin{array}{l}\text { The management has taken the necessary action to } \\
\text { attain the objectives regarding accreditation. }\end{array}$ & & 0.605 & & \\
\hline 42 & $\begin{array}{l}\text { The management does not discriminate between } \\
\text { academic staff and/or units. }\end{array}$ & & 0.662 & & \\
\hline 43 & $\begin{array}{l}\text { The management is sufficient deals with the problems } \\
\text { of the academic staff. }\end{array}$ & & 0.776 & & \\
\hline 44 & Academic tenures are granted objectively. & & 0.638 & & \\
\hline 46 & $\begin{array}{l}\text { Infrastructure allocations and budget allowances are } \\
\text { granted to the units objectively and/or realistically. }\end{array}$ & & 0.751 & & \\
\hline 48 & $\begin{array}{l}\text { The rate of development of our school has been good } \\
\text { in recent years. }\end{array}$ & & 0.618 & & \\
\hline
\end{tabular}


The items no. $5,6,8,9,16,17,18,19,20,21,22,25,27,30,31,33,34,35,36,40,45,47,49,50,51$ and 52 were removed from the scale, as their factor loadings were low.

Factors shown in Table 3 are as follows:

Factor 1 (Adequacy of School Infrastructure): Items no. 1, 2, 4, 7, 10, 11, 12, 13, 14, 15

Factor 2 (Management): Items no. 23, 24, 26, 28, 29, 32

Factor 3 (Social Opportunities): Items no. 37, 38, 39

Factor 4 (Courses/Education): Items no. 41, 42, 43, 44, 46, 48 Each factor was named taking into account the items gathered under the factors.

Tablo 4: Faktör analizi uyum iyiliği tablosu

Table 4: Goodness of fit in item factor analysis

\begin{tabular}{cccccccc}
\hline & \multicolumn{9}{c}{ RMSEA 90\% CI } \\
CFI & TLI & RMSEA & Lower & Upper & $\boldsymbol{\chi}^{\mathbf{2}}$ & df & p \\
\hline 0.268 & 0.238 & 0.122 & 0.116 & 0.127 & 2.894 & 1274 & $<.001$ \\
\hline
\end{tabular}

Table 4 illustrates the goodness of fit indices of the model developed for the sample. A $\chi^{2} / \mathrm{df}$ value below 3 , a TLI value of 0.238 , a CFI value of 0.268 and a RMSEA value of 0.112 indicate that the model's fit is good.

The second important feature that a measurement tool is supposed to have is reliability. A reliable measurement tool gives approximately the same numerical results in the measurements carried out successively about the same property. When a group takes a reliable test two or three times, each person in the group should get roughly the same score in all of them (14).

In a sense, reliability is a part of validity. A test needs to measure a property consistently so that it can measure it accurately. However, reliability does not guarantee validity. An exceptionally reliable test may have a very low level of validity for the purpose for which it is used (14).

To measure the reliability of Likert-type scales, Cronbach's alpha and McDonald's omega tests are recommended. Cronbach's alpha and McDonald's omega are a measure of internal consistency of the items in the measurement tool (10). For a measurement tool to be considered sufficient, it needs to have a reliability coefficient that is close to 1 . If the Cronbach's alpha coefficient is below 0.40, the measurement tool is considered unreliable. If the coefficient is between 0.40 and 0.59 , the tool has low reliability. A Cronbach's alpha coefficient between 0.60 and 0.79 indicates that the measurement tool is quite reliable. If the coefficient is between 0.80 and 1.00 , the tool is considered highly reliable (14). In order to test internal consistency, Cronbach's alpha coefficient of the Job Satisfaction Evaluation Scale for Academic Staff was calculated. Cronbach's alpha coefficient was found to be 0.882 , and McDonald's omega coefficient was calculated to be 0.883 . Accordingly, Table 5 shows that the internal consistency/reliability of the scale is high.

Tablo 5: Ölçeğin toplam güvenirlik katsayısı Akademik Personel İş Memnuniyeti Değerlendirme Ölçeği

Table 5: The total reliability coefficient of the Job Satisfaction Evaluation Scale for Academic Staff

\begin{tabular}{ccc}
\hline & Cronbach's $\boldsymbol{\alpha}$ & McDonald's $\boldsymbol{\omega}$ \\
\hline Job Satisfaction Evaluation Scale for Academic Staff & 0.806 & 0.842 \\
\hline
\end{tabular}


Tablo 6: Ölçeğin soru bazlı güvenirlik katsayıları ve madde toplam korelasyonları

Table 6: Item-based reliability coefficients and item-total correlations of the scale

\section{if item dropped}

\begin{tabular}{cccc} 
& item-rest correlation & Cronbach's $\boldsymbol{~}$ & McDonald's $\boldsymbol{\omega}$ \\
\hline 1 & 0.32638 & 0.880 & 0.881 \\
2 & 0.48762 & 0.878 & 0.879 \\
3 & 0.21412 & 0.883 & 0.884 \\
4 & 0.30685 & 0.881 & 0.881 \\
7 & 0.23876 & 0.882 & 0.882 \\
10 & 0.47721 & 0.878 & 0.879 \\
11 & 0.31373 & 0.881 & 0.881 \\
12 & 0.49006 & 0.878 & 0.879 \\
13 & 0.64556 & 0.875 & 0.876 \\
14 & 0.57295 & 0.876 & 0.877 \\
15 & 0.36636 & 0.880 & 0.880 \\
23 & 0.69807 & 0.874 & 0.875 \\
24 & 0.61188 & 0.876 & 0.877 \\
26 & 0.71651 & 0.875 & 0.875 \\
28 & 0.29808 & 0.881 & 0.881 \\
29 & 0.52722 & 0.878 & 0.878 \\
32 & 0.30635 & 0.881 & 0.881 \\
37 & 0.39963 & 0.882 & 0.883 \\
38 & 0.28745 & 0.881 & 0.881 \\
39 & 0.29264 & 0.882 & 0.883 \\
41 & 0.38878 & 0.879 & 0.880 \\
42 & 0.33498 & 0.880 & 0.881 \\
43 & 0.45899 & 0.878 & 0.879 \\
44 & 0.21712 & 0.882 & 0.882 \\
46 & 0.29591 & 0.881 & 0.881 \\
48 & 0.25240 & 0.885 & 0.885 \\
\hline
\end{tabular}

The reliability coefficient is calculated as an analysis method that establishes the extent to which the items constituting the measurement tool are related to the entire measurement tool and is commonly used for selecting items $(1,4,5,6,7,10)$. Item-total score analysis is conducted to measure the construct validity and construct reliability of scales. Item-total score correlation coefficients explain the relationship between the scores for the test items and the total score of the test. A positive and high item-total score correlation implies that the items sample similar behaviour and that the test's internal consistency is high. In a test where Likert-type rating scales are used, the item-total score correlation is calculated using the correlation coefficient (10). A high correlation coefficient for an item suggests that the connection of that item to the theoretical construct is high, meaning that the item can effectively and sufficiently measure the behaviour that is intended to be measured (23). For item selection, it is recommended that the correlation coefficient be higher than 0.20 or even 0.25 . It is noted that items with a correlation coefficient between 0.20 and 0.30 can be included in the test if deemed necessary, probably after making some revisions to those items, but items with a correlation coefficient below 0.20 should never be included in the test. Generally speaking, items with an item-total score correlation coefficient of 0.30 and above distinguish individuals well (5).

According to the literature, items with a factor loading below 0.20 should be removed from the scale (23). Twenty-six items were found to have a factor loading below 0.20 and thus were removed from the scale. 
In this case, the scale can be used to determine the satisfaction of academic staff in other faculties on the basis of the selected factors and the reverse-scoring items.

\section{Discussion and Conclusion}

The findings of the study suggest that the Job Satisfaction Evaluation Scale for Academic Staff is reliable and valid for academics serving in Faculty of veterinary medicine and can be used to evaluate their satisfaction regarding their workplace environment. The four factors in the scale contain a total of 26 items. In another study, a scale named Academic Environment Evaluation Scale was developed to determine the level of job satisfaction of academics from various faculties of Pamukkale University, and a reliability and validity study was conducted for this purpose. Three factors containing a total of 27 items were included in the scale, and it was found that the academics had the highest satisfaction from communication with students and the lowest satisfaction from their working conditions (8). Additionally, in a study conducted regarding job satisfaction of lecturers from various faculties of Mehmet Akif Ersoy University, an 18-item scale containing four factors was developed. The factors were named perceived organisational support, job satisfaction, extra-role behaviour and cooperation environment. Based on the findings, it was recommended that lecturers socialise more and have good relationships with the management to increase their job satisfaction. The explained variance and KMO value of the scale developed for that study are 74.632 and 0.926 , respectively., which are higher than the values in our study (2). The large sample size and the fact that the study was conducted across all faculties must be the underlying reasons why the factor loadings and the explained variance are high.

Another study conducted across eight public universities in Turkey found that the most important factor for job satisfaction of academics was their opportunity to make decisions freely (18). A wide range of studies conducted to identify the factors affecting job satisfaction of academics are available in the literature. The factors affecting job satisfaction vary even among different faculties in the same university where such studies were conducted. The sociodemographic variables affecting the factors and the total scores that can be obtained from a form for which a reliability and validity study has been conducted may vary even among the departments/faculties in the same university. For such reasons, more reliable information can be obtained if such type of studies are applied as a common measurement tool across all veterinary faculties in Turkey.

The mission of the European Association of Establishments for Veterinary Education (EAEVE) is to evaluate, promote and further develop the quality and standard of veterinary medical establishments and their teaching within, but not limited to, the member states of the European Union (12). Established in 2010 in Turkey, "the Association for the Evaluation and Accreditation of Veterinary Institutes and Programmes (VEDEK) is a non-governmental organisation committed to contributing to raising the quality of veterinary training in Turkey by carrying out accreditation, evaluation and informing activities for veterinary training institutions and programmes". Similar studies can be conducted annually in all veterinary faculties across the country using scales whose validity and reliability have been confirmed, as a result of which the universities can identify their strengths and weaknesses according to the factor scores of academics, and thus administrators of the universities can consider such results when making decisions for improvement and development of the faculties and universities in line with the missions of the EAEVE and VEDEK. Mainly, this will enable common assessments to be made in the meetings of VEDEK and similar commission in Turkey as well as allowing common decisions to be made to take measures in an effort to make collective improvements.

In conclusion, the measurement of the level of job satisfaction of academics in universities, the major institutions that generate knowledge, and the implementation of measures for improving their satisfaction will directly or indirectly contribute to the development of countries and enhancement of social welfare. 


\section{References}

1. Allen MJ, Yen WM (2002): Introduction to measurement theory. Long Grove, IL: Waveland Press.

2. Alparslan AM (2014): The antecedent of Job Satinsfaction, Satinsfaction From The University And Extra-Role Behavior: A Survey. Mehmet Akif Ersoy Üniversitesi Sosyal Bilimler Enstitüsü Dergisi, 6(11), 82-101.

3. Balcı A (1995): Sosyal Bilimlerde Araştırma Yöntem, Teknik ve İlkeler. Ankara Üniversitesi Eğitim Bilimleri Fakültesi, Ankara, Türkiye.

4. Bland JM, Altman DG (1997): Statistics notes: Cronbach's alpha. BMJ, 314 (7080), 572.

5. Bonett DG (2002): Sample size requirements for testing and estimating coefficient alpha. Journal of Educational and Behavioral Statistics, 27, 335-340. doi:10.3102/10769986027004335.

6. Bonett DG (2003): Sample size requirements for comparing two alpha reliability coefficients. Applied Psychological Measurement, 27, 72-74. doi:10.1177/0146621602239477.

7. Bonett DG (2010): Varying coefficient meta-analytic methods for alpha reliability. Psychological Methods, 15, 368-385. doi:10.1037/a0020142. PMID 20853952.

8. Buluş M (2004): Pamukkale Üniversitesi öğretim elemanlarında akademik ortam düzeyi. Pamukkale Üniversitesi Eğitim Fakültesi Dergisi, 16 (16), 1-7.

9. Büyüköztürk Ş (2007): Sosyal Bilimler İçin Veri El Kitabı, İstatistik, Araştırma Deseni, SPSS Uygulamaları ve Yorum. Pegem Yayıncılık, Ankara, Türkiye.

10. Cronbach LJ, Shavelson RJ (2004): My current thoughts on coefficient alpha and successor procedures. Educational and Psychological Measurement, 64 (3), 391-418. doi:10.1177/0013164404266386.

11. Dempsey PA, Dempsey AD (2000): Using nursing research process, critical evaluation and utilization. 5th Edition, Lippincott, Philadelphia-New York.

12. EAEVE (2019): European Asssociation of Establishments for Veterinary Education. Erişim: https://www.eaeve.org/ Erişim tarihi: 18.02.2019

13. Erdoğan İ (1996): İşletme Yönetiminde Örgütsel Davranış. Avcıŏlu Basım Yayım, İstanbul, Türkiye.

14. Field A (2005). Discovering statistics using SPSS. 2nd ed. London Sage.

15. Gözüm S, Aksayan S (2003): Kültürler arası ölçek uyarlaması için rehber II: psikometrik özellikler ve kültürlerarası karşılaştırma. Hemşirelikte Araştırma Geliştirme Dergisi, 4, 9-14.

16. Kaiser H (1974): An index of factor simplicity. Psychometrika, 39, 31-36.

17. Kaiser HF (1958): The varimax criterion for analytic rotation in factor analysis. Psychometrika, 23, 187.

18. Karaman F, Altunoğlu AE (2007): Kamu üniversiteleri öğretim elemanlarının iş tatmini düzeyini etkileyen faktörler. Yönetim ve Ekonomi: Celal Bayar Üniversitesi İktisadi ve İdari Bilimler Fakültesi Dergisi, 14, 109-120.

19. Locke EA, Latham GP (1990): Work motivation and satisfaction: Light at the end of the tunnel. Psychological science, 1(4), 240-246.

20. Özgüven İE (1999): Psikolojik testler. 3. bask1, PDREM yayınları, Ankara, Türkiye.

21. Paksoy HM (2007): Üniversitelerde akademik personelin iş memnuniyeti: Harran üniversitesi örneği. Karamanoğlu Mehmetbey Üniversitesi Sosyal ve Ekonomik Araştırmalar Dergisi, 2007(1), 138-151.

22. Tengilimoğlu D (2005): Hizmet işletmelerinde liderlik davranışları ile iş doyumu arasındaki ilişkinin belirlenmesine yönelik bir araştırma. Ticaret ve Turizm Fakültesi Dergisi, 1, 23-45.

23. Tezbaşaran A (1997): Likert tipi ölçek geliştirme klavuzu. 2. Baskı. Türk Psikologlar Derneği Yayınları, Ankara, Türkiye.

24. Tuzcu MA (2016): Ankara Üniversitesi Tömer'de çalışan akademik ve idari personelin iş tatmin düzeyinin ve iş tatminine etki eden faktörlerin belirlenmesi. Ankara Üniversitesi SBF Dergisi, 71(1), 161-197.

25. Ulusoy T (1993): İşletmelerde İş Tatmini ve Karşılaştırmalı Bir Uygulama Araştırması. Doktora Tezi, İstanbul Üniversitesi Sosyal Bilimler Enstitüsü, İstanbul, 15-29.

26. VEDEK (2019): Veteriner Hekimleri Ĕ̈itim Kurumlarl ve Programları Değerlendirme ve Akreditasyon Derneği. Erişim: http://www.vedek.org.tr/index.php?option=com_content\&view=article\&id=49\&Itemid=56\&lang=tr Erişim tarihi: 18.02 .2019 


\section{Annex:}

The questionnaire form is containing all questions:

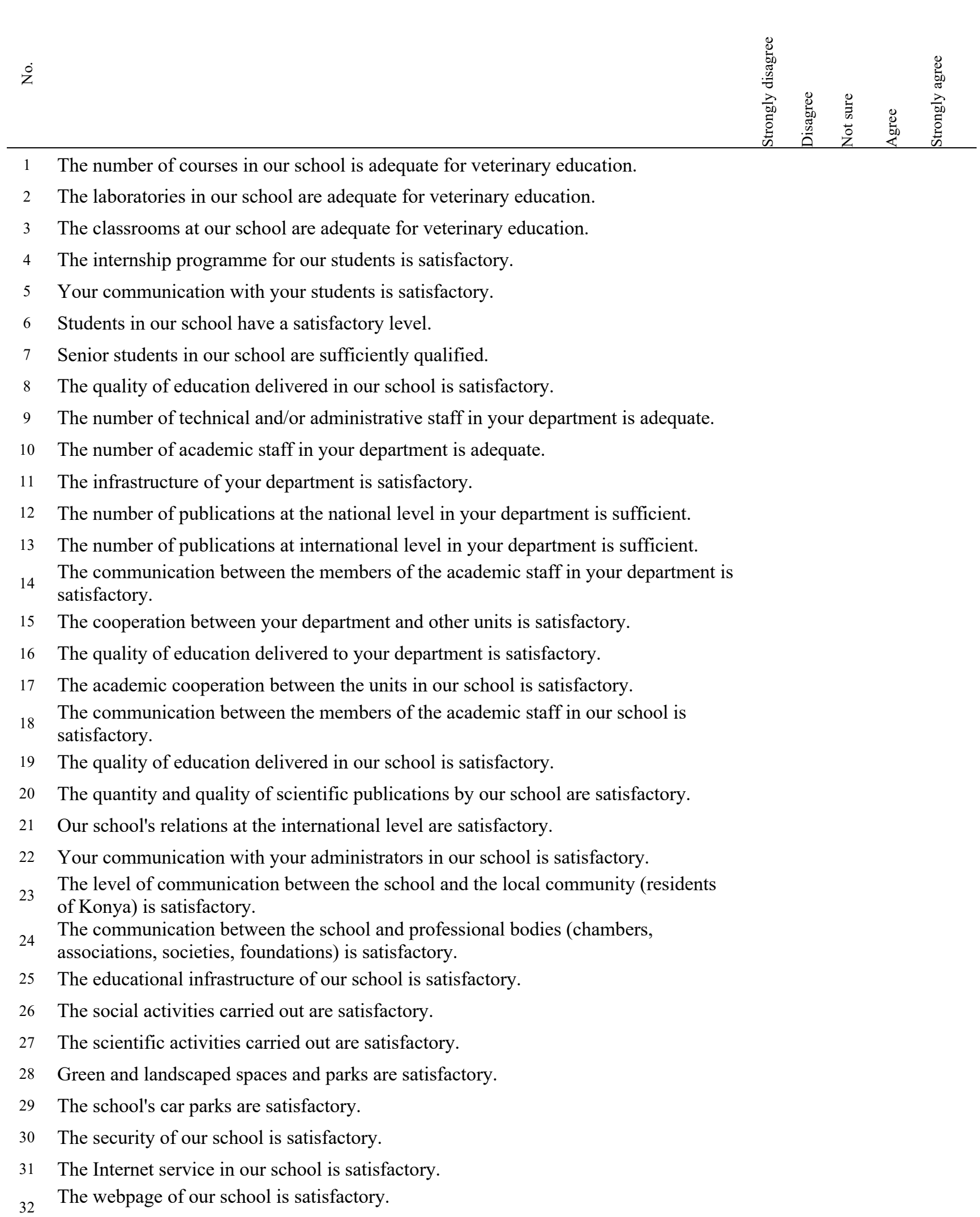




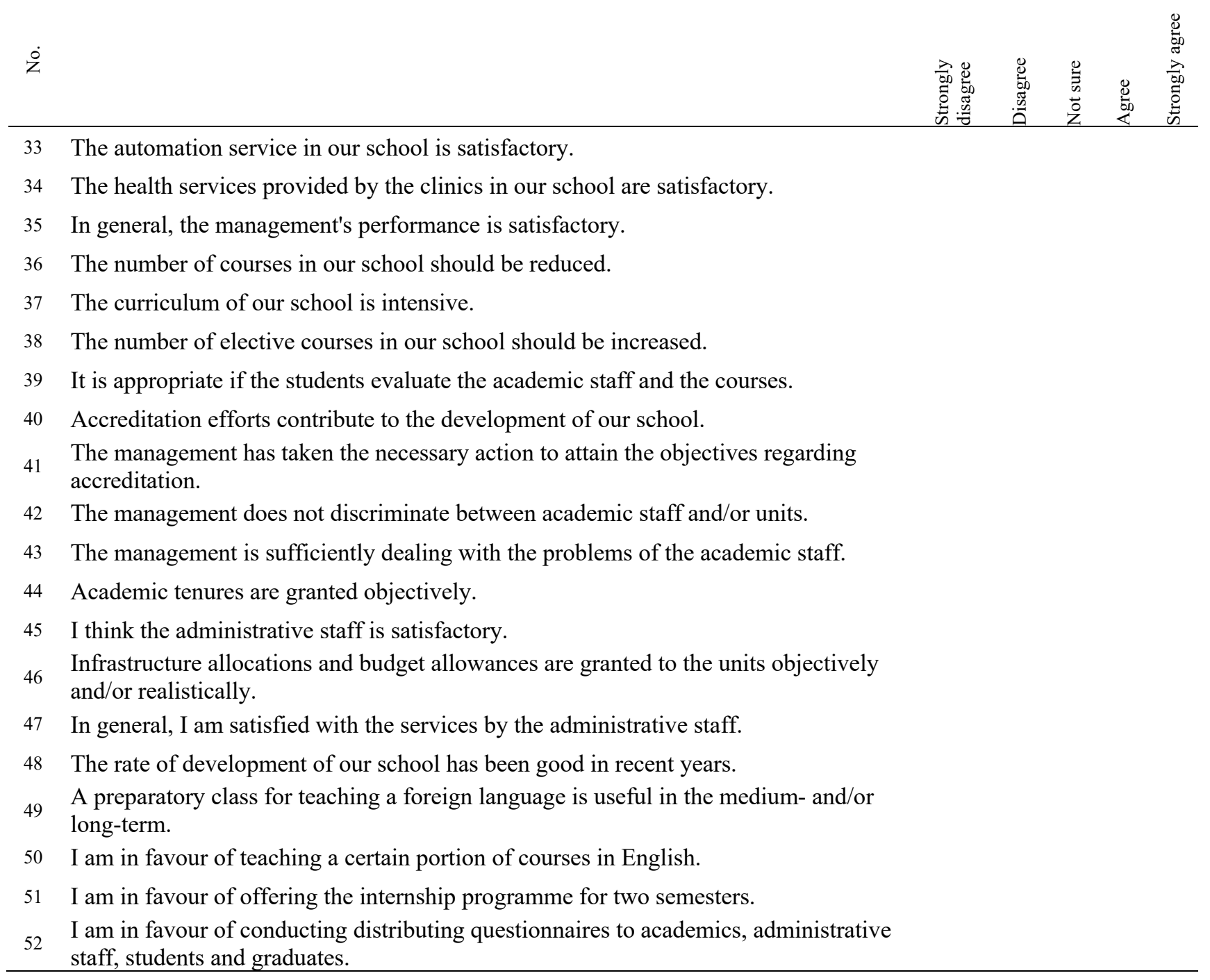

